\title{
Remote sensing semi-automatic measurements approach for monitoring bioenergetic crops of Miscanthus spp.
}

\author{
Katarzyna Kubiak, Karol Rotchimmel \\ Remote Sensing Department, Institute of Aviation, Al. Krakowska 110/114, 02-256 Warsaw, Poland \\ Krzysztof Stereńczak \\ Laboratory of Geomatics, Forest Research Institute, Sękocin Stary, 3 Braci Leśnej St., 05-090, Raszyn, Poland
}

Marta Damszel

Department of Entomology, Phytopathology and Molecular Diagnostics, University of Warmia and Mazury in Olsztyn, Prawocheńskiego 17, $10-721$ Olsztyn, Poland

\section{Zbigniew Sierota}

Department of Forestry and Forests Ecology, University of Warmia and Mazury in Olsztyn, Plac Łódzki 2, 10-727 Olsztyn, Poland

Abstract: The paper presents the review of the potential application of remote sensing techniques at ground, air, and satellite levels in monitoring, yield assessment for bioenergy crops and the evaluation of natural grass communities of Miscanthus spp. According to the Directive 2009/28, the EC countries are obliged to increase the participation of energy production from renewable energy sources by $20 \%$ by 2020 . This objective can be achieved in part by using biomass from high energy plantations. Monitoring of Miscanthus growth, one of the most prospective crop species, is important because of its use as bioenergy crop, to evaluate quality and quantity, and for environmental reasons. As Miscanthus is a non-native species in Europe, its uncontrolled spread may threaten the diversity of native species. Contrary to the traditional field-based observations of Miscanthus communities, the remote sensing provide suitable data enable the acquisition of precise data about biomass state and habitat quality. Such methods are highly efficient tools for precise quantitative assessment in agriculture and for the monitoring of natural Miscanthus communities.

\section{Introduction to Miscanthus}

The use of different agricultural resources for energy purposes can have positive effect in reduction of fossil fuel consumption and decrease of air pollutant emissions. In addition, it entails a range of social benefits, such as reduced unemployment rates and improved living conditions of the rural population due to the creation of new jobs and additional income sources. Miscanthus belongs to grass family (Poaceae) and is particu-

\section{Autor korespondujący:}

Katarzyna Kubiak, katarzyna.kubiak@ilot.edu.pl

\section{Artykuł recenzowany}

nadesłany 05.11.2019 r., przyjęty do druku 06.12.2019 r. larly suitable for energy purposes because of its physiological adaptation to a $\mathrm{C} 4$ photosynthesis pathway. Due to the more efficient use of solar energy, water, and nutrients compared to C3 plants, C4 plants are characterized by a $50 \%$ more intensive biomass growth [30]. In Europe, Miscanthus has been cultivated for about 50 years. It was initially used as an ornamental plant, but is now increasingly being planted as a bioenergy crop. It produces a thick, rigid, spongy stem with a height of $200-350 \mathrm{~cm}$. The most commonly cultivated variety is the giant Miscanthus (Miscanthus x giganteus), which does not produce fertile seeds and must therefore be vegetatively reproduced. Miscanthus reaches its full capacity in the third year after planting [9]. Some genotypes can spread uncontrolled by seeds (alien species, potentially invasive).

Dry matter yield is significantly dependent on the crop year and the harvesting date and ranges between 1-3 t/ha in the first year, 8-15 t/ha in the second and about 25-30 t/ha in the third and in subsequent years [9]. The energy value of Miscan- 
thus straw is approximately $17-19 \mathrm{MJ} / \mathrm{kg}$ dry weight, which is comparable to that of wood, but below that of bituminous coal [5]. The weight of 1.5 to 2.5 tons of dry Miscanthus straw provides the energy equivalent of 1 ton of coal or of $600-1,000$ liters of heating oil [17].

\section{Introducing to remote sensing methods}

Traditional, mathematical methods of forecasting crop yields throughout the growing season are based on models that use climatic data, soil conditions, and other environmental data as inputs to describe plant growth and development, photosynthesis intensity, evapotranspiration, and yield of biomass for a particular crop [2]. Although these models are based on physiological and physical agronomy aspects, they poorly fulfill prognostic functions under soil spatial variability, stress conditions or management practices [2]. The use of remote sensing methods in crop monitoring is considered a valuable tool for crop forecasting and production management in agriculture. These techniques can compete with traditional modeling approaches due to their large-scale range of operation and their capacity to analyze multiple wavelengths of the spectrum and to obtain valuable biomass data, which is important for efficient agricultural production [23]. Numerous studies indicate that the phase of plant development, stress conditions, and crop yields are expressed in changes in the intensity of the spectral response from the vegetation cover, and can be expressed quantitatively using spectral vegetation indicators $[2,19]$.

\section{Monitoring methods in Miscanthus biomass}

Monitoring of the abundance and growth of Miscanthus is an important procedure both of its use of bioenergy crop, the desired quality or quantity of crops, and due to ecological reasons, such as the origin of the plants. As an alien species in Europe, the uncontrolled spread causes a significant threat to the conservation of native species and, as a consequence, to local biodiversity [25]. In the field of agriculture, remote sensing has recently been used to obtain information and to support the management systems in precision farming [14]. Passive remote sensing methods rely on the analysis of patterns of reflectance (spectral signatures - reflection of sunlight from the object, depending on the wavelength of the light) of the vegetation cover, recorded from a distance (aerial or satellite).

In [18] authors calculated the value of the GRVI (Green-Red Vegetation Index) by remote sensing methods for mapping and determining the phenology of plant ecosystems in Japan. They used this indicator to carry out long-term observations of $M$. sinensis leaf color changes depending on the vegetation phase, especially in early spring and autumn. For this purpose, they used an automatic, rotary hemispherical spectrographic system and a fisheye camera mounted on top of a tower or mast in each of the studied fields. Measurements of the remote sensing GRVI and NDVI (Normalized Difference Vegetation Index) indexes were performed daily, and the purpose of the study was to estimate the usefulness of GRVI values as a phenological indicators of vegetation and as an ecological indicator. The authors' observations indicate that GRVI values decreased in response to changes in the plant cover, even in the middle of the growth period when changes in leaf color and density were hard to distinguish visually. Researchers have demonstrated that GRVI values are clearly associated with phenological differences related to seasonal changes in the plant cover, particularly leaf color changes, and that this indicator may also be useful for determining vegetation distribution and for ecosystem typing by remote sensing [18].

In [1] authors used the remote sensing, ground-level monitoring technology for energy grass crops to evaluate maximization of dry matter content. The platform was located on a 38-meter high tower above an arable field. The pictures were taken between $12 \mathrm{pm}$ and $15 \mathrm{pm}$ each day, and the algorithm especially developed for this study allowed the real-time assessment of the acquired data. The system was used to monitor, among others, Miscanthus and millet crops in red, green, and blue $(R G B)$ and infrared $(C I R)$ images, which were continuously transmitted over a wireless network and analyzed. The spatial resolution of the images, after generating the mosaic and the georeference, was achieved at $120 \mathrm{~mm} /$ pixel. The image acquisition system, the photo mosaic, and the geographic reference on the map were developed based on geographic information system (GIS). To verify the predictability of the Miscanthus yield on the basis of remote sensing data, the cumulative NDVI value was correlated with actual biomass data obtained from terrestrial crop yield measurements in 2011 . The results showed that the data correlated $\left(\mathrm{R}^{2}\right)$ at $64.4 \%$, indicating a high potential prediction of biomass yield on the basis of real-time remote sensing data from arable land after calibration of the field processing method using field data [1].

In [13] authors designed and developed, near real-time, where a remote sensing platform for monitoring biomass growth of Miscanthus prior to harvesting. The proposed crop monitoring system scanned 35 acres of crop in 15 minutes, generating 91 multispectral images per day. Multispectral Miscanthus photos with a resolution of $100 \mathrm{~mm} /$ pixel were generated, and high-quality daily images were generated automatically during the growing season (Li et al. 2014). Remote sensing data was calculated for NDVI for the entire vegetation season. The results of the analysis showed that the crop monitoring system [13] could generate a high-resolution yield map of Miscanthus, with $84.96 \%$ correlation with daily biomass growth. These data, as compared to the system proposed [13], provided a $20 \%$ better effectiveness of biomass accuracy estimation.

Height of the grass affects biomass yield. In [33] authors proved a strong correlation between the height and yield of the Miscanthus crop. These observations have prompted researchers to use laser scanning with a LIDAR technology (Light Detection and Ranging) (SICK LMS 291) to monitor Miscanthus cultivation in Terrestrial Laser Scanning (TLS) systems: static and dynamic (on the tractor) for plants height measurements [32]. Authors [32] have proposed the use of the Look-Ahead Yield Monitor $(L A Y M)$ as a cost-efficient and more accurate method for estimating the size of giant miscanthus in real time, predicting its yield, selection of appropriate equipment, and optimal winter harvest parameters. The effectiveness of using LIDAR was $92 \%$ at a crop density of 62 stems $/ \mathrm{m}^{2}$ to $98.2 \%$ at a density of $85 \mathrm{stems} / \mathrm{m}^{2}$. When LIDAR the scanner was mounted on a tractor and traversed along the edge of the $M$. giganteus field, the stem height was recorded with an accuracy from $93.5 \%$ at a speed of $0.41 \mathrm{~m} / \mathrm{s}$ to $98.5 \%$ (0.05 m of error) at a speed around $0.22 \mathrm{~m} / \mathrm{s}$. Each data frame, consisting of 361 measurement points, has been corrected for LIDAR positions relative to the field, using a scanner angle correction algorithm that enables reliable measurement of grass height in both stationary and dynamic modes. Based on the obtained data, the authors found a strong linear correlation between the mass of the Miscanthus stems and their height ( $\mathrm{R}$ square 0.86 ).

The use of the LIDAR Scanner in Miscanthus yield estimation has also been described by previous authors [6, 26], who, among the limitations of using LIDAR for estimating Miscanthus yields, listed weather-related conditions as the most important limitations. Even in light weather conditions, light wind can 
move the blades of the grass, contributing to the unreliability of the measurements. Another limitation in performing dynamic measurements is the need to use a slow speed of the LIDAR movement, because speed is inversely proportional to the data density per unit length traveled. Here, one of the solutions is to use a system of double LIDAR or multiple repetitions [32].

The undisputable advantage of ground-based remote sensing systems located near the monitored target is their accuracy and lack of dependence on cloudiness and radiation (reflected from clouds). Data acquisition from such monitoring is less costly than e.g. hyper-visual satellite images and is not as time-limited as the use of satellites, because images of terrestrial systems can be taken daily as needed. These techniques are therefore independent of aerial measurement systems that depend on weather, flight conditions, and time resolution, especially satellites, which have a limited time resolution $[1,13]$. The exception are drones which can fly under clouds level and are less weather dependent than satellites or pilot aircraft. As it is coupled with aerial and satellite imagery analysis, a terrestrial, ground-based system of real-time data processing algorithms enables efficient crop management at every stage of plant development [15].

\section{Satellite and aerial methods for Miscanthus crops}

Satellite and aerial remote sensing methods have been widely used for many years for mapping and vegetation classification, habitat mapping, biomass estimation in natural and anthropogenic ecosystems, and to determine the plant phenological stage [7].

In [24] authors proposed an integrated empirical model for forecasting Miscanthus spp. crops, based on biomass yield data and NDVI values obtained from georeferenced satellite remote sensing data. The authors included variable crop conditions in the proposed model, such as soil type, humidity, and climatic data. Analysis of satellite data indicates that Miscanthus cultivation is largely independent of the soil type and are higher on medium and light soils than on heavy, clay soils. Although the acquired NDVI values from satellite imagery show a correlation with the in situ yield of Miscanthus, the authors suggest that the input parameters of the mathematical model describing the shoot density of the plant should be enriched with information about their height, as it also determines total Miscanthus biomass.

The use of remote-controlled drones as well as helicopters, airplanes, and balloons enables the acquisition of high-resolution aerial imagery with better resolution than that from satellite systems. Aerial remote sensing systems were also applied to identify Miscanthus species abundance in natural and anthropogenic grasslands. In [16] authors obtained hyperspectral images using the AISA (Airborne Imaging Spectrometer for Applications) system and demonstrated a method of Matched Filtering $(M F)$ as a specialized type of analysis of a mixture pattern of spectra to estimate the number (expressed as a derivative of the stem diameter and plant height) and density of $M$. sacchariflorus and Phragmites australis in wet meadows, where these plants are the dominant species. Images with a spectral range from $398 \mathrm{~nm}$ to $993 \mathrm{~nm}$ (at $10 \mathrm{~nm}$ ) were obtained using 68 spectral channels of the radiometric resolution of 16 bits, which enables the identification of small differences in the reflectance values between the pixels. Hyperspectral images were obtained from an airplane from the altitude of $1.438 \mathrm{~m}$, and the area of each pixel represented $1.5 \mathrm{~m} \times 1.5 \mathrm{~m}$ of vegetation cover [16]. The results obtained with the MF model and in situ data showed a high correlation for M. sacchariflorus density $(r=0.89)$ and for the total number of stalks $(\mathrm{r}=0.78)$.
For $P$. australis observation, slightly lower $\mathrm{r}$ values $(0.43$ and 0.58 , respectively) were obtained. The authors point out that the greatest limitation of the proposed method is the difficulty in distinguishing the sought material on the image from background reflection $[21,31,16]$.

In remote sensing monitoring of grasses in multi-species communities, important elements are the plant characteristics and the growth rate. These elements should be taken into account when modeling the biomass yields of these crops. In [16] authors believe that the probable cause of the differences in the effectiveness of the proposed method is the morphology of the growth of the examined grasses. The leaves of M. sacchariflorus are relatively soft and tend to develop more horizontally, covering almost the entire area under the plant (seen from the top). This allows hyperspectral sensors to capture the pure spectrum of M. sacchariflorus, unaffected by background materials such as soil, stones, or understory plants. On the other hand, the leaves of $P$. australis are relatively hard, rigid, and grow upright, thus revealing the soil and lower plants, which results in a hyperspectral mixed spectrum of $P$. australis, soil, and understory plants. The morphological differences between these two plants are the key to estimate the abundance and distribution of M. sacchariflorus and P. australis in the studied area. These authors believe that the critical point of the MF method is to determine the characteristics of the spectral signature of a single plant of a species as a reference sign. For Miscanthus, this was possible due to its leaf morphology, whereas for $P$. australis, the proposed method was not satisfactorily effective because of the difficulty of selecting pixels containing only the selected grass without disturbing the background [16].

In Japan, authors tested [7] a UAV remote sensing using method as multi-rotor radar ("Falcon-PARS - UAV for Photogrammetry and Remote Sensing") with a wetland vegetation monitoring camera in an area dominated by Phragmites australis and M. sacchariflorus. It took $11 \mathrm{~min}$ and 10 secs to take pictures of the whole area of $100 \mathrm{~m} \times 200 \mathrm{~m}$ from a height of $30 \mathrm{~m}$. Images of spatial resolution $(1 \mathrm{~cm})$ and position accuracy of less than $1 \mathrm{~m}$ (RMSE (Root Mean Square Error) were $0.974 \mathrm{~m}$ and $0.360 \mathrm{~m}$ ) were used to produce high resolution mosaics. Based on the remote sensing data, it could be confirmed that $P$. australis and $M$. sacchariflorus can be identified by visual interpretation, because the results showed that the remote sensing data correlated in more than 90 percent with data from in situ observations. The authors conclude that such systems can be used for the direct identification of grassy plant species as a non-destructive alternative to field research. Because of the low altitude of the flight (below the cloud level), air-to-ground observation is possible even on cloudy days, allowing observation at any time of the year [7].

The UAV (Unmanned Aerial Vehicle), compared to the classic manned airborne remote sensing methods, provides low operational complexity and competitive costs. In addition, remote sensing devices located on UAVs provide high spatial, spectral, and temporal resolution data $[3,8,4]$. In [12] authors used the UAV method to map vegetation in the Niida River valley near Fukushima, Japan. The research was conducted the aerial photography using a UAV and created a vegetation map from the aerial photographs taken by the UAV. A controlled quadcopter with a multispectral camera and ArcGis9 software was used to analyze plant communities dominated by $P$. australis, Typha domingensis, and M. sacchariflorus. From the photographs taken by the UAV, shape and number of plants could be shown in detail, enabling precise distinguishing in terms of morphology. Photos of the UAV also enabled to precisely recognize the distribution of many plant communities due to the accurate vegetation maps [12]. The schematic diagram of the general process of mapping using the UAV method is shown in Fig. 1. 


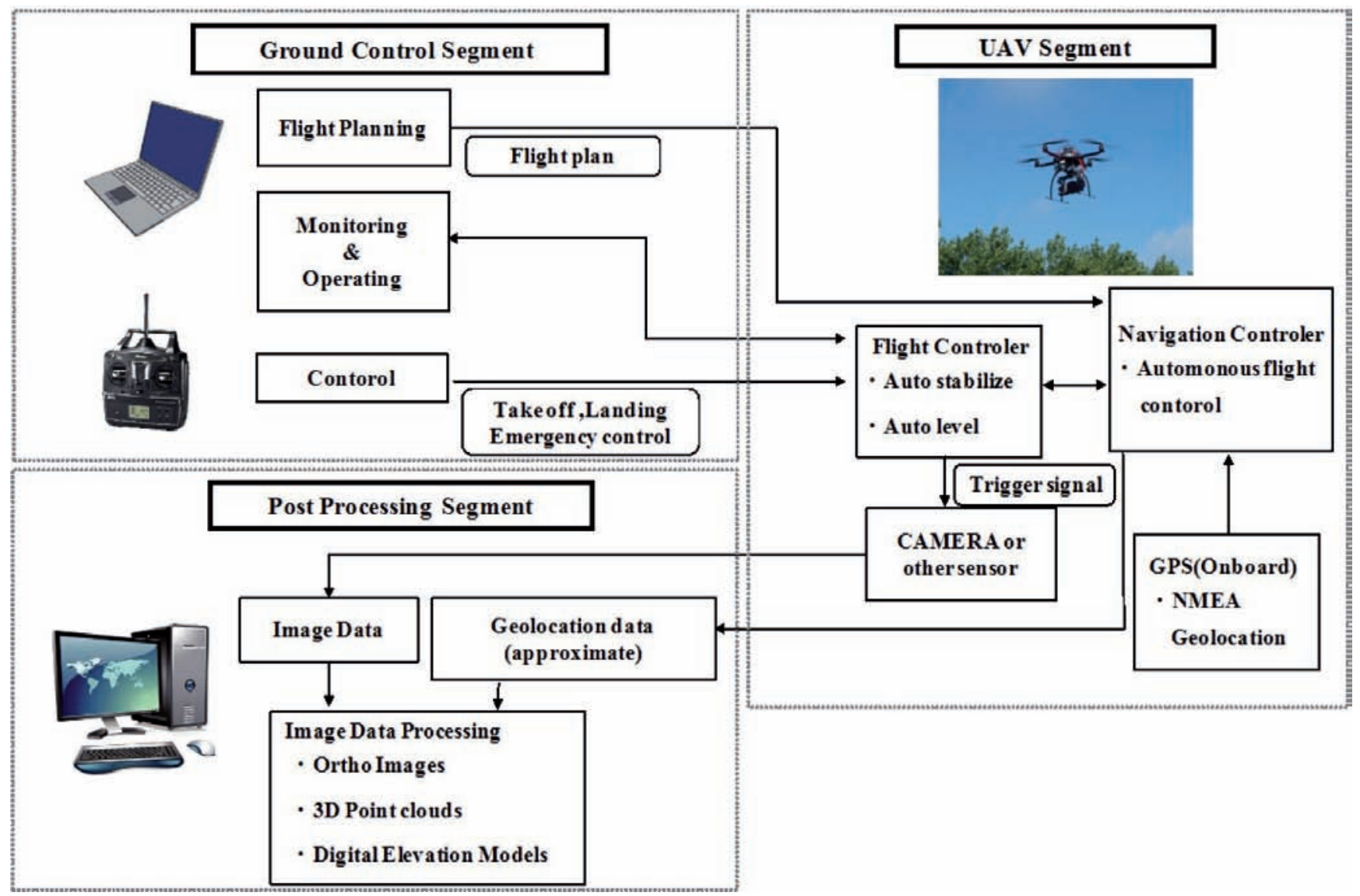

Fig. 1. Diagram of the mapping process with UAV method used in plant communities (P. australis, Typha domingensis, and M. sacchariflorus) monitoring in Japan [12]

Rys. 1. Schemat procesu mapowania metodą UAV zastosowaną w zbiorowiskach roślin (P. australis, Typha domingensis i M. sacchariflorus) w Japonii [12]

The UAV remote sensing methods for monitoring natural and anthropogenic vegetation cover are a good supplementation to existing satellite monitoring methods and aircraft platforms, due to their low cost, accuracy, weather resistance, and high resolution of generated images [27]. In addition, remote sensing UAV technology can be used for long-term monitoring especially where vegetation field studies are difficult, e.g. in raised bogs. This method also enables to maintain the reproducibility of photographed positions in areas inaccessible for field trips. The application of UAVs reduces the risk of working in difficult terrain conditions while obtaining highly accurate measurements $[20,7,12]$.

\section{Remote Sensing of natural Miscanthus spp. communities monitoring}

Remote sensing methods for vegetation monitoring have been applied to study Miscanthus communities, mainly to confirm a high correlation between vegetation index (based on the proportion of reflectance of visible light and near-infrared) and radiation actively used in photosynthesis - IPAR (Intercepted Photosynthetically Active Radiation) [11]. In [29] authors showed that measuring reflectance spectra allows for a more accurate and reliable estimate of the energy PAR (Photosynthetically Active Radiation), even in the final stages of the growing season, compared to the traditional standard longitudinal photosynthesis PAR sensors. Furthermore, the waveform data of reflectance are useful for monitoring aging and ripening of Miscanthus plants which, in a more advanced stage of crop development, affect the quality of the biomass during the combustion process [10]. Due to spectral signatures of crops it is possible to monitor the important qualitative and quantitative features at every developmental stage of the Miscanthus crop [11].

Remote sensing methods can also be used to estimate the efficiency of water use - in the scale of the cultivation crop and of the region [22]. In cellulosic crops for energy purposes, such as Miscanthus spp, biomass production depends largely on the intensity of irrigation, because the cultivation of cellulose can consume more water than food crops [28]. Previous data, obtained both from field measurements and from mathematical modeling [22] have proven that the Miscanthus spp. crops are characterized by higher productivity than other C4 plants and consumes more water than, for example, maize. Further analysis showed that Miscanthus had the greatest efficiency of water use in relation to the production of net biomass [22]. With the same level of water use, millet and Miscanthus sequester similar amounts of carbon, while the maize cultivation carbon balance was negative. The authors of the above mentioned study therefore stress the need to increase the amount of data from field observations in order to improve ecosystem modeling and to conduct analyses on a wider scale.

Remote sensing methods have also been applied in the analysis of the biodiversity of natural grassland ecosystems with Miscanthus as the dominant genus. Economical, large-scale, long-term, and continuous monitoring of plant populations dominant in communities is one of the few available tools to assess biodiversity in wet land plant communities which are difficult to access. The analysis of large-scale grass communities is extremely costly and time-consuming [34]. Therefore, a method that can rapidly and efficiently collect data over a large area is crucial for effectively monitoring vegetation conditions, such as the degree of coverage or the diversity of dominant species in wetland grass ecosystems. 
The analysis of Miscanthus spectral signatures was also used [11] on the selection and frequency of its genotypes, which is important because of its origin and adaptive abilities to new habitats. European Miscanthus plantations were measured with the spectral signature and results were obtained as the AIPAR (accumulated IPAR). Measurements and analysis of the spectral signatures allowed to separate the species with a high productivity, depending on the habitat [11].

\section{Conclusions}

The development of diagnostic and forecasting tools based on, simultaneously or separately, field and satellite remote sensing methods may be useful for the improvement of crop yields and the systematic supply of energy crops biomass. Data obtained from satellite monitoring can also be used as a support tool for national statistical system monitoring of biomass yield within a country or region.

The use of aerial, and satellite remote sensing methods allows the monitoring of Miscanthus crops cultivated for bioenergy purposes and the evaluation of natural grass communities, with a precise division into plant groups even in areas difficult to access. Table 1 contains comparison of remote sensing methods used in Miscanthus monitoring with advantages and disadvantages. In general, remote sensing systems provide high resolution images and are therefore a valuable alternative to field research due to limiting or eliminating vegetation damage. Images were obtained from aerial systems such as the AISA (Airborne Imaging Spectrometer for Applications), multi-rotor radar ("Falcon-PARS") and analyzed by special designed method to estimate the number and density of Miscanthus spp. among other grass in wet meadows.

The results of aerial remote sensing application, showed that data correlated in more than 90 percent with data from in situ observations, what gives good prognosis that such systems can be used for the direct identification of grassy plant species in non-destructive field research. The use of aerial remote-sensing platforms, because of the low altitude of the flight enables acquisition of high-resolution aerial imagery even on cloudy days, what is advantages in comparing to satellite systems.

Satellite remote sensing methods provide data of large scale monitoring. What gives useful tool for the improvement of Miscanthus crop yields and biomass production management strategies, systematic supply of energy crops biomass and gives a support tool for national statistical system monitoring of biomass yield within a global, country or region scale. Moreover, the analysis of large-scale remote sensing data were used in mathematical modeling in order to assess the yield and water balance in the cultivation of Miscanthus energy crops to evaluate water use efficiency, depending on the cultivated ecosystem type in the United States.

The findings from various studies confirm that remote sensing methods are an effective tools for monitoring biomass of plant communities such as Miscanthus. In the future, RS based methods will be improved by decreasing the time spent on field research and labor, and can also be used to quantitatively evaluate plant height of Miscanthus, and what is more important, can provide homogenous data in regional or global scale

\section{Acknowledgements}

This work was supported by the Institute of Aviation in Poland under Grant: Launch of The Earth Observation Mission Control Center (EOMC2) using available infrastructure to develop methods and procedures for processing satellite data (EUMETSAT, Sentinel, Landsat).

\section{References}

1. Ahamed T., Tian L., Jiang Y.S., Zhao B., Liu H., Ting K.Ch., Tower remote-sensing system for monitoring energy crops; image acquisition and geometric corrections. "Biosystems Engineering", Vol. 112, No. 2, 2012, 93-107, DOI: 10.1016/j.biosystemseng.2012.03.003.

2. Aparicio N., Villegas D., Casadesus J., Araus J.L., Royo C., Spectral vegetation indices as non-destructive tools for determining durum wheat yield, "Agronomy Journal Abstract - AGROClimatolOGY”, Vol. 92, No. 1, 2000, 83-91, DOI: 10.2134/agronj2000.92183x.

3. Berni J., Zarco-Tejada P., Suarez L., Fereres E., Thermal and narrowband multispectral remote sensing for vegetation monitoring from an unmanned aerial vehicle. "IEEE Transactions on Geoscience and Remote Sensing", Vol. 47, No. 3, 2009, 722-738, DOI: 10.1109/TGRS.2008.2010457.

4. Berni J., Zarco-Tejada P., Suarez L., Fereres E., Remote sensing of vegetation from UAV platforms using lightweight multispectral and thermal imaging sensors. "ISPRS Archives", Vol. 38, No. 6, 2014.

5. Collura S., Azambre B., Finqueneisel G., Zimny T., Weber J.V., Miscanthus $\times$ Giganteus straw and pellets as sustainable fuels. "Environmental Chemistry Letters", Vol. 4, No. 2, 2006, 75-78, DOI: 10.1007/s10311-006-0036-3.

6. Ehlert D., Heisin M., Sources of angle-dependent errors in terrestrial laser scanner-based crop stand measurement. "Computers and Electronics in Agriculture", Vol. 93(C), 2013, 10-16, DOI: 10.1016/j.compag.2013.01.002.

7. Ishihama F., Watabe Y., Oguma H., Validation of a high-resolution, remotely operated aerial remote-sensing system for the identification of herbaceous plant species. "Applied Vegetation Science", Vol. 15, No. 3, 2012, 383-389, DOI: 10.1111/j.1654-109X.2012.01184.x.

8. Jensen A., Han Y. Chen Y.Q., Using aerial images to calibrate the inertial sensors of a low-cost multispectral autonomous remote sensing platform (AggieAir), [in:] IEEE International Geoscience and Remote Sensing Symposium, 2, 2009, 555-558, DOI: 10.1109/IGARSS.2009.5417547.

9. Jeżowski S., Yield traits of six clones of Miscanthus in the first 3 years following planting in Poland. "Industrial Crops and Products", Vol. 27, No. 1, 2008, 65-68, DOI: $10.1016 /$ j.indcrop.2007.07.013.

10. Jørgensen U., Genotypic variation in dry matter accumulation and content of $N, K$ and $C l$ in Miscanthus in Denmark. "Biomass and Bioenergy", Vol. 12, No. 3, 1997, 155-169, DOI: 10.1016/S0961-9534(97)00002-0.

11. Jørgensen U., Mortensen J., Ohlsson C., Light interception and dry matter conversion efficiency of Miscanthus genotypes estimated from spectral reflectance measurements. "New Phytologist", Vol. 157, No. 2, 2002, 263-270, DOI: $10.1046 / \mathrm{j} .1469-8137.2003 .00661 . x$.

12. Kaneko K., Nohara S., Review of Effective Vegetation Mapping Using the UAV (Unmanned Aerial Vehicle) Method. "Journal of Geographic Information System", Vol. 6, No. 6, 2014, 733-742, DOI: 10.4236/jgis.2014.66060.

13. Li L., Tian L., Ahamed T., Preharvest monitoring of biomass production, [in:] Shastri Y., Hansen A., Rodríguez L., Ting K.C. (Eds), Engineering and Science of Biomass Feedstock Production and Provision, Springer, New York, US, 2014, 61-83.

14. Liaghat S., Balasundram S.K., A Review: the role of remote sensing in precision agriculture. "American Journal of Agricultural and Biological Sciences", Vol. 5, No. 1, 2010, 50-55, DOI: 10.3844/ajabssp.2010.50.55. 
Table 1. Comparison of different methods used in vegetation crop (Miscanthus yield) monitoring Tabela 1. Porównanie metod monitorowania plonu biomasy (Miscanthus spp.)

\begin{tabular}{|c|c|c|}
\hline $\begin{array}{l}\text { Remote sensing } \\
\text { technology used to } \\
\text { study Miscanthus }\end{array}$ & Description & Pros \\
\hline Ground-based & $\begin{array}{l}\text { Ground-based remote sensing techniques } \\
\text { consisting of laboratory and field tests on } \\
\text { a small scale using such tools as multi- or } \\
\text { hyperspectral cameras, terrestrial laser } \\
\text { scanning, spectrometers, etc. } \\
\text { Ground-based techniques give } \\
\text { opportunities to determine the dynamics } \\
\text { of the yield. } \\
\text { It is possible to predict (from } 65 \% \text { to } \\
85 \% \text { accuracy via multi- or hyperspectral } \\
\text { images or } 92 \% \text { to } 98.5 \% \text { accuracy via } \\
\text { Lidar) Miscanthus yield in the early stage } \\
\text { of the vegetative season. }\end{array}$ & $\begin{array}{l}\text { - high resolution data and accuracy, } \\
\text { - no atmospheric effect, } \\
\text { - possibility of carrying out systematic monitoring, } \\
\text { - real-time assessment of the acquired data, } \\
\text { - the ability to analyze multiple wavelengths of the } \\
\text { spectrum (multi- or hyperspectral cameras), } \\
\text { - ability to obtain 3D data using point clouds, } \\
\text { - can be use/treat as reference data, } \\
\text { - precise selection and measurement of } \\
\text { sample position. }\end{array}$ \\
\hline Aerial-based monitoring & $\begin{array}{l}\text { Remote sensing techniques at the aerial } \\
\text { level mainly use aerial photographs } \\
\text { acquired by multi- or hyperspectral } \\
\text { cameras and aerial laser scanners. They } \\
\text { can be installed both on small UAV or } \\
\text { manned airborne platforms. } \\
\text { Aerial techniques are more effectiveness } \\
\text { of monitoring of agricultural and } \\
\text { ecological systems than the satellite-based } \\
\text { monitoring (high correlation with in situ } \\
\text { data 90\%) }\end{array}$ & $\begin{array}{l}\text { - high resolution data, } \\
\text { - high accuracy, } \\
\text { - no atmospheric effect on low flight altitude, } \\
\text { - flight possibility even on cloudy days, allowing } \\
\text { observation at any time of the year, } \\
\text { - possibility of carrying out systematic monitoring } \\
\text { (rather, not every day), } \\
\text { - real-time assessment of the acquired data, } \\
\text { - the ability to analyze multiple wavelengths of the } \\
\text { spectrum (multi- or hyperspectral cameras), } \\
\text { - ability to obtain 3D data using point clouds, } \\
\text { - non-destructive alternative to field research, } \\
\text { - opportunities to determine the dynamics of } \\
\text { the yield, } \\
\text { - UAV compared to the classic manned airborne } \\
\text { remote sensing methods, provides low operational } \\
\text { complexity and competitive costs, } \\
\text { - superiority of air methods for mapping vegetation } \\
\text { communities difficult to reach in comparison to } \\
\text { traditional field observations, } \\
\text { - enabling precise distinguishing in terms } \\
\text { of morphology, } \\
\text { - data acquisition for areas difficult to access, } \\
\text { - precise division into plant groups, } \\
\text { - low altitude of the flight enables acquisition of high- } \\
\text { resolution aerial imagery even on cloudy days, what } \\
\text { is advantages in comparing to satellite systems. }\end{array}$ \\
\hline $\begin{array}{l}\text { Satellite-based } \\
\text { monitoring }\end{array}$ & $\begin{array}{l}\text { Using Satellite-based monitoring, multi- } \\
\text { or hyperspectral image data can be } \\
\text { obtained. Satellite data are best suited } \\
\text { for conducting remote sensing analyzes } \\
\text { on a country, regional or global scale but } \\
\text { due to the low resolution (resolution of } \\
\text { images obtained from satellite systems } \\
\text { is relatively low compared to that of } \\
\text { airborne systems) it does not give very } \\
\text { high accuracy results. }\end{array}$ & $\begin{array}{l}\text { - the ability to analyze multiple wavelengths of } \\
\text { the spectrum (more than in other remote sensing } \\
\text { techniques with a higher radiometric resolution), } \\
\text { - non-destructive alternative to field research, } \\
\text { - cost-effective way especially in large areas, } \\
\text { - opportunities to determine the dynamics of the yield } \\
\text { in global scales, } \\
\text { - rough classification of vegetation, } \\
\text { - continuously providing mapping of large surfaces at } \\
\text { different spatial and temporal resolutions, } \\
\text { - possibility to mapping vegetation and } \\
\text { soil parameters, } \\
\text { - support national statistical system monitoring of } \\
\text { biomass yield within a country or region, } \\
\text { - results of analyzes on a large scale, } \\
\text { - data acquisition for areas difficult to access, } \\
\text { - easily accessible multi-temporal data, } \\
\text { - ability to obtain 3D data using point clouds (from } \\
\text { stereo-matching), }\end{array}$ \\
\hline
\end{tabular}




\begin{tabular}{|l|c|}
\hline \multicolumn{1}{|c|}{ Cons } & Source \\
\hline - problematic, especially for large areas, & {$[33]$} \\
- only provide point-to-point information, & {$[1]$} \\
- destructive field research, & {$[32]$} \\
- high cost of acquisition for a larger area, & {$[26]$} \\
- time-consuming for a larger area, & {$[6]$} \\
- weather-related conditions (light wind can move & {$[13]$} \\
the blades of the grass, contributing to the & \\
unreliability of the measurements), & \\
- measurement accuracy depends on the & \\
technology used. & \\
& \\
\hline
\end{tabular}

- problematic, especially for very large areas (UAV),

- high cost of acquisition for a larger area (manned airborne platforms),

- time-consuming for a larger area (UAV),

- weather-related conditions (light wind can move the blades of the grass, contributing to the unreliability of the measurements),

- measurement accuracy depends on the GPS connection (Lidar),

- flight dependent on weather,

- the field lighting conditions should be taken into account.
15. Lopatina A., Rapid assessment of energy biomass resources using aerial photographs from unmanned aerial vehicles, Master's thesis in Forestry and Environmental Engineering, Finnish-Russian Cross-Border University (CBU), Faculty of Science and Forestry, University of Eastern Finland, 2013.

16. Lu S., Funakoshi S., Shimizu Y., Ishii Y., de Asis A.M., Ajima M., Washitani I., Omasa K., Estimation of plant abundance and distribution of Miscanthus sacchariflorus and Phragmites australis using matched filtering of hyperspectral image. "Eco-Engineering", Vol. 18, No. 2, 2006, 65-70, DOI: 10.14877/agrmet2.2006sp.0.70.0.

17. Majewska-Sawka A., Miscanthus. A clean energy/ Miskant olbrzymi. Czysta energia, 11, 2009, 34-35 (in Polish).

18. Motohka T., Nasahara K.N., Oguma H., Tsuchida S., Applicability of green-red vegetation index for remote sensing of vegetation phenology. "Remote Sensing", Vol. 2, No. 10, 2010, 2369-2387, DOI: 10.3390/rs2102369.

19. Nordberg M.L., Evertson J., Vegetation index differencing and linear regression for change detection in a Swedish mountain range using Landsat TM and ETM+ imagery. "Land Degradation and Development", Vol. 16, No. 2, 2003, 139-149. DOI: 10.1002/ldr.660.

20. Oguma H., Usami M., Shimazaki H., Ishihama F., A high-resolution remote sensing by radio control helicopter and apply to species discrimination of individual level of wetland herbaceous plant. $57^{\text {th }}$ Annual Conference of Ecological Society of Japan, Tokyo, 15-20 March 2010, Abstract.

21. Oki K., Funakoshi Y., Inamura M., Study on estimation of the specific land cover ratio in a pixel using hyper-spectral data. Estimation of the vegetation cover ratio. "Journal of the Remote Sensing Society of Japan", Vol. 20, No. 3, 2000, 241-257, DOI: 10.11440/rssj1981.20.241.

22. Qin Z., Zhuang Q., Chen M., Impacts of land use change due to biofuel crops on carbon balance, bioenergy production, and agricultural yield, in the conterminous United States. "GCB Bioenergy", Vol. 4, No. 3, 2012, 277-288, DOI: $10.1111 /$ j.1757-1707.2011.01129.x.

23. Quarmby N.A., Milnes M., Hindle T.L., Silleos N., The use of multi-temporal NDVI measurements from AVHRR data for crop yield estimation and prediction. "International Journal Remote Sensing", Vol. 14, No. 2, 1993, 199-210. DOI: 10.1080/01431169308904332.

24. Richter G.M., Agostini F., Barker A., Costomiris D., Qi A., Assessing on-farm productivity of Miscanthus crops by combining soil mapping, yield modelling and remote sensing. "Biomass and Bioenergy", Vol. 85, 2016, 252-261, DOI: 10.1016/j.biombioe.2015.12.024.

25. Smith L.L., Barney J.N., The relative risk of invasion: evaluation of Miscanthus $\times$ giganteus seed establishment. "Invasive Plant Science \& Management", Vol. 7, 2014, 93-106, DOI: 10.1614/IPSM-D-13-00051.1.

26. Sritarapipat T., Rakwatin P., Kasetkasem T., Automatic rice crop height measurement using a field server and digital image processing. "Sensors", Vol. 14, No. 1, 2014, 900-926, DOI: 10.3390/s140100900.

27. Strecha C., Fletcher A., Lechner A., Erskine P., Fua P., Developing species specific vegetation maps using multi-spectral hyperspatial imagery from unmanned aerial vehicle. "ISPRS Annals", 2012, 1-3, DOI: 10.5194/isprsannals-I-3-311-2012.00061-5.

28. VanLoocke A., Bernacchi C.J., Twine T.E., The impacts of Miscanthus $\times$ giganteus production on the Midwest US hydrologic cycle. "GCB Bioenergy", Vol. 2, No. 4, 2010, 180-191, DOI: 10.1111/j.1757-1707.2010.01053.x. 
29. Vargas L.A., Andersen M.N., Jensen C.R., Jørgensen U., Estimation of leaf area index, light interception and biomass accumulation of Miscanthus sinensis 'Goliath' from radiation measurements. "Biomass and Bioenergy", Vol. 22, No. 1, 2002, 1-14, DOI: 10.1016/S0961-9534(01)00058-7.

30. Wang C., Guo L., Li Y., Wang Z., Systematic comparison of $C_{3}$ and $C_{4}$ plants based on metabolic network analysis. "BMC Systems Biology", Vol. 6(Suppl 2), 2012, S9, DOI: 10.1186/1752-0509-6-S2-S9.

31. Williams A.P., Hunt J.E.R., Estimation of leafy spurge cover from hyperspectral imagery using mixture tuned matched filtering, "Remote Sensing of Environment", Vol. 82, No. 2-3, 2002, 446-456, DOI: 10.1016/S0034-4257(02)00061-5.
32. Zhang L., Grift T.E., A LIDAR-based crop height measurement system for Miscanthus giganteus. "Computers and Electronics in Agriculture", Vol. 85, 2012, 70-76, DOI: 10.1016/j.compag.2012.04.001.

33. Zub H.W., Arnoult S., Brancourt-Hulmel M., Key traits for biomass production identified in different Miscanthus species at two harvest dates. "Biomass and Bioenergy", Vol. 35, No. 1, 2011, 637-651,

DOI: $10.1016 /$ j.biombioe.2010.10.020.

34. Everitt J.H., Anderson G.L., Escobar D.E., Davis M.R., Spencer N.R., Andrascik R.J., Use of Remote Sensing for Detecting and Mapping Leafy Spruge (Euphoribia estula), "Weed Techn", Vol. 9, No. 3, 1995, 599-609.

\section{Półautomatyczne pomiary metodą teledetekcji do monitorowania bioenergetycznych upraw Miscanthus spp.}

Streszczenie: W pracy przedstawiono przegląd najnowszej literatury dotyczącej możliwości zastosowania technik teledetekcyjnych naziemnych, lotniczych i satelitarnych do monitorowania, prognozowania plonu oraz oceny zbiorowisk naturalnych bioenergetycznych traw należących do Miscanthus spp. Zgodnie z dyrektywą 2009/28 kraje należące do Unii Europejskiej zobowiązane są do 2020 r. do zwiększenia udziału produkcji energii z odnawialnych źródeł o 20\%. Cel ten może zostać częściowo osiągnięty przez wykorzystywanie biomasy na cele energetyczne. Monitorowanie wzrostu bioenergetycznej trawy - miskanta, jednego z najbardziej perspektywicznych gatunków roślin uprawnych, jest istotne nie tylko ze względu na jego przeznaczenie jako uprawy bioenergetycznej, ale także ze względów środowiskowych. Ponieważ miskant jest gatunkiem obcym w Europie, jego niekontrolowane rozprzestrzenienie się może zagrozić różnorodności gatunków rodzimych. W przeciwieństwie do tradycyjnych metod obserwacji zbiorowisk miskanta, metody teledetekcyjne dostarczają dokładnych danych o stanie biomasy i jakości zbiorowisk. Metody te są wysoce wydajnymi narzędziami do precyzyjnej oceny ilościowej i jakościowej upraw oraz monitorowania naturalnych zbiorowisk roślinności, m.in. miskanta.

\section{dr inż. Katarzyna Kubiak \\ katarzyna.kubiak@ilot.edu.pl ORCID: 0000-0002-4156-3139}

Absolwentka kierunku Biologia w Szkole Głównej Gospodarstwa Wiejskiego oraz kierunku Ochrony Środowiska na Wydziale Biologii Uniwersytetu Warszawskiego. Od 2015 r. pracuje jako adiunkt w Zakładzie Teledetekcii, Instytutu Lotnictwa i aktualnie zajmuje się pozyskiwaniem oraz analizą danych spektralnych (spektrometria laboratoryjna i polowa, UAV, satelity): roślinności w rolnictwie precyzyjnym, analizie wpływu zanieczyszczeń na środowisko naturalne, analizie wpływu zmian klimatu na roślinne ekosystemy naturalne. Główne zainteresowania naukowe to optymalizacja konfiguracji sensorów optycznych kamer wielospektralnych do obrazowania biomasy oraz elementów przyrodniczych.

\author{
mgr Karol Rotchimmel \\ karol.rotchimmel@ilot.edu.pl \\ ORCID: 0000-0002-7561-212X
}

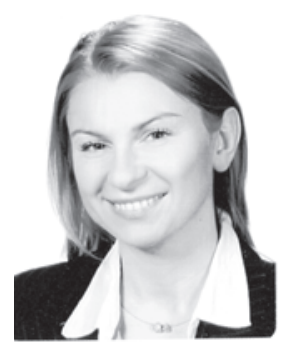

Absolwent Wydziału Geodezji i Kartografii Politechniki Warszawskiej. Od 2014 r. pracuje w Zakładzie Teledetekcji Instytutu Lotnictwa. Zajmuję się fotogrametrią i teledetekcją, odpowiedzialny za przetwarzanie zdjęć lotniczych z kamer niemetrycznych w projekcie HESOFF i FITOEXPORT. lego zainteresowania naukowe dotyczą modelowanie 3D i zaawansowanych metod wizualizacji.

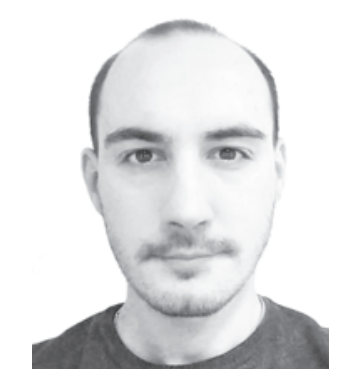


dr hab. inż. Krzysztof Stereńczak

k.sterenczak@ibles.waw.pl

ORCID: 0000-0002-9556-0144

Absolwent Wydziału Leśnego SGGW w Warszawie. Aktualnie pracuje w Zakładzie Geomatyki Instytutu Badawczego Leśnictwa w Sękocinie Starym. Zajmuje się szeroko rozumiana geomatyką i teledetekcją, w szczególności leśnictwem precyzyjnym a przede wszystkim lotniczym skanowaniem laserowym i jego wykorzystaniem winwentaryzacji i monitorowaniu środowiska leśnego.

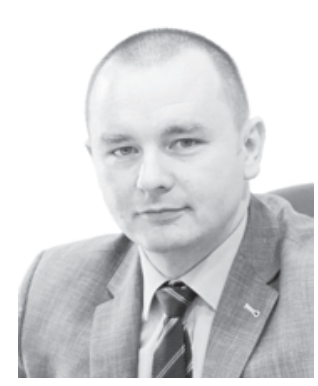

dr hab. Marta Damszel

marta.damszel@uwm.edu.pl ORCID: 0000-0001-5479-1432

Absolwentka Wydziału Biologii UWM w Olsztynie. Zatrudniona w tejże Uczelni na Wydziale Kształtowania Środowiska i Rolnictwa, adiunkt w Katedrze Entomologii, Fitopatologii i Diagnostyki Molekularnej, UWM w Olsztynie. Aktywność naukowo badawcza ukierunkowana na diagnostykę klasyczną i molekularną chorób roślin rolniczych i leśnych.

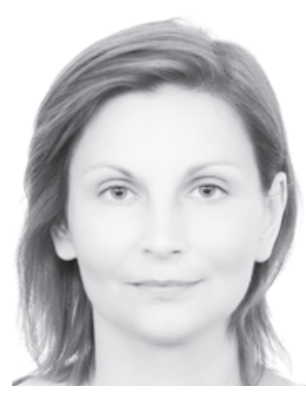

\section{prof. dr hab. Zbigniew Sierota}

zbigniew sierota@uwm edu.p

ORCID: 0000-0003-3419-7799

Absolwent Wydziału Leśnego SGGW. Aktualnie pracuje na Wydziale Kształtowania Środowiska i Rolnictwa UWM w Olsztynie. Zajmuje się chorobami lasu, monitorowaniem stanu zdrowotnego drzew leśnych, interpretacją zdjęć lotniczych w aspekcie stanu sanitarnego lasu.

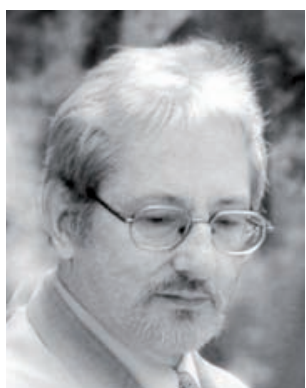

